\title{
Science Generic Skills Improvement through Student Centered Learning
}

\author{
Siska Desy ${ }^{1}$, Fatmaryanti $^{2}$, Sarwanto $^{3}$ \\ ${ }^{1,3}$ Sebelas Maret University, Indonesia \\ ${ }^{2}$ Muhammadiyah Purworejo University, Indonesia \\ Correspondence: sd_fatmaryanti@yahoo.com; sarwanto@fkip.uns.ac.id
}

\begin{abstract}
This study was aimed to determine the effectiveness of student centered learning (SCL) in improving science generic skills of high school students. The study was confined to the application of the 2 models based on SCL are guided inquiry model and multiple representations model. This research was quasi experiment with a control group pretest-posttest design. The study was conducted in 2 high schools in Purworejo district. The independent variable was a guided inquiry model in the first study while in the second study was multi representation model. Both studies had the same dependent variable, namely science generic skills of high school students. Results of research have shown that this two learning models are proven more effective in improving science generic skills of high school students than conventional learning model.
\end{abstract}

Keywords: science generic skills; student centered learning 


\section{INTRODUCTION}

A generic skill is the skill which can be applied across a variety of subject domains and takes longer to acquire than domain-dependent (Lim, 1999; Yeung, 2007). For science learning, generic skills are named science generic skills. Liliasari (2007) suggested that in order to win the global competition, science learning needs to be changed from a scientific study into thinking through science. The ability to think and act based on scientific knowledge possessed called a science generic skills.

In physics course, science generic skills that can be develop are: direct observation, indirect observation, sense of scale, symbolic language, logical consistency, causality, modeling, logical inference and abstraction (Brotosiswoyo, 2000; Sudarmin, 2007). Initial research study also revealed that science generic skills of high school students in the district purworejo categorized as low (Loi et al, 2015). Science generic skills are low is also experienced at a higher level (Fatmaryanti \& Sarwanto, 2014).

Students are the center of the educational enterprise, and their cognitive and affective learning experiences should guide all decisions as to what is done and how (Arends, 2013). Learning system that has been done that the conventional learning system, instructional thick with atmosphere and it is less appropriate to the dynamics of science and technology so rapidly. The learning approach Student Centered Learning (SCL) has the potential to encourage students to learn more actively and independently. However the activity and independence need to be guided in order to continue the dynamic and have a high level of competence that is with the help of learning model (Wright, 2011). Learning model that can be used is a learning model that is characterized by active and independent students.

As the boundary problem, learning model used is a guided inquiry model. While learning model is a representation of multi multi representation learning model that has been developed by Carolan, et. al (2013). This study was aimed to determine the increase in generic science skills through guided inquiry learning model and multi-representation.

\section{LITERATURE REVIEW}

\section{Student Centered Learning (SCL)}

Student Centered Learning (SCL) is an approach to learning that empowers students to be the center of attention during the learning process (Sanjaya, 2014). Learning that is rigid instruction of educators changed to learning which enables learners to adjust to his ability and behavior directly in accepting their learning experience. Rationale of SCL is teory constructivist learning (Arends, 2013). constructivist theory comes from learning theories that focus on the learning process of learners behavior change itself and experienced directly to 
establish the concept of learning and understanding. Furthermore, the concept of the learning experience of the triangle Dale has proven that learning experience for themselves the real or actual condition and control the learning process was the fulfillment of a better learning experience than learning by observing (Slavin, 2009).

One model of learning that uses SCL approach is the inquiry model. Inquiry model is a model of learning that gives students the chance to have a real experience and active learning, students are trained how to solve problems and make decisions (Khulthau, et. Al, 2007). The purpose of using inquiry model is to develop the ability to think in a systematic, logical and critical or develop intellectual abilities as part of the mental process so that students are not only required to master the subject matter, but how students can develop their potential (Sanjaya, 2014).

Another learning models that can be applied is a learning model multi representation. Many researchers have said multi representation just as the way students and teachers represent a concept in various ways, such as mathematical, visual, graphics and others (Izhak \& Sherin, 2003; Kohl \& Finkelstein, 2007). But in this study researchers used the definition of multi-representation as a learning model are also stressing the involvement of students in learning. The learning model multi representation used referring to the results of research Carolan, et al (2008) and Tytler, et el (2013) who developed a framework of multi representation in the planning topics ( $\mathrm{I}$ and $\mathrm{F}$ ), the role of teachers and students in learning through the representation of the topic ( $\mathrm{S}$ and $\mathrm{O}$ ).

\section{Science generic skills}

The development of the world could be faced with a new paradigm of science learning, which provides a range of experiences for students to understand and guide them to use the scientific knowledge (Liliasari, 2007). This means that in developing the competence and understanding of science students to consider the basic skills of students, in addition to has the ability in understanding the concept, they also must be able to integrate basic skills held with the knowledge of science to meet the needs of students in different life situations (Tanwil \& Liliasari, 2014). The ability to think and act based on the scientific knowledge possessed by the frame of mind of science called generic science skills (Liliasari, 2007). With the skills these students can learn science by baik.Brotosiswoyo (2001) suggests generic science capabilities critical to building the personality and higher-order thinking. That is because the ability of generic science as the basis for high-level thought processes that include the ability to think creatively, critically, decision-making and problem solving everyday life. Generic science skills (KGS) is known as core skills, essential skills and basic 
skills, and is something that is needed in the job (Yeung, 2007). Generic science skills help students to learn and demonstrate how good learning. Learning science will be full of the thinking developed through 9 kinds of generic skills science (Brotosiswoyo, 2000) which includes (1) direct observation, (2) indirect observation, (3) sense of scale, (4) the symbolic language, (5) logical self consistency, (6) inference logic, (7) causality, (8) matemathical modeling, and (9) concept formation.

\section{METHOD}

This research was quasi experiment with Control Group Pre-test Post-test Design. The study was conducted at SMAN 2 and SMAN 4 Purworejo in Central Java. In each of these studies there have been two variables, namely the independent variable $(\mathrm{X})$ and the dependent variable (Y). The independent variable in the first study was the use of SCL approach using guided inquiry learning model, while in the second study, the independent variables such as the use of learning model SCL approach with multi-representation. Both studies had the same dependent variable, namely generic science skills. The first study population was students of class XI SMA Negeri 2 Purworejo, while the second study, the research population was the class XI students in SMA Negeri 4 Purworejo. The sample in this research was determined by purposive sampling technique. Analysis using descriptive statistical analysis techniques to present or express their level of generic skills of students in the material science of thermodynamics. Increased generic science skills before and after the learning activity was calculated by the formula $\mathrm{g}$ factor (gain score normalized) as follows (Sugiyono, 2009).

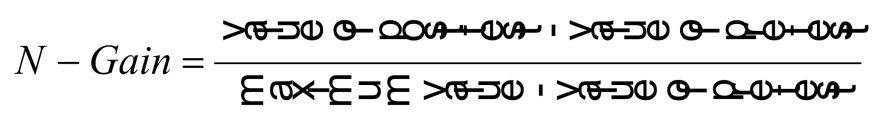

Table 1: N-Gain criteria

\begin{tabular}{|l|l|}
\hline Range of $N$-Gain & Information \\
\hline $\mathrm{g} \geq 0,7$ & high \\
\hline $0,3 \leq \mathrm{g}<0,7$ & medium \\
\hline $\mathrm{g}<0,3$ & low \\
\hline
\end{tabular}

\section{RESULT AND DISCUSSION}

On the application of the model pembelajran guided inquiry in SMAN 2 Purworejo, the value of the gain scores KGS of experiments is better than the gain score of control class. It can be caused by the level of participation or activity of students in finding a concept in class experiment more leverage. It also can not be separated from the philosophy of inquiry model which states that the model of inquiry learning is a learning model that emphasizes the 
student's activity to the fullest to seek and find, meaning inquiry model puts the student as a subject of study. This means that there is a positive effect of inquiry learning model to the generic skills science science class XI SMA Negeri 2 Purworejo. In general the results of the calculation of the gain scores with the application of inquiry model compared with conventional models gain score of the application as presented in Table 2 have shown the average value of gain score better on inquiry learning model of 0.74 and included a high category while for the conventional model simply by 0.48 and included in the medium category.

Table 2: Results of Test N-Gain on Guided Inquiry Learning in SMAN 2 Purworejo

\begin{tabular}{|l|l|l|}
\hline Class & N-gain & Information \\
\hline Experiment & 0.74 & High \\
\hline Control & 0.48 & Medium \\
\hline
\end{tabular}

On the application of multi representation model of learning in SMAN 4 Purworejo, the value of the gain scores KGS of the experiments also obtained better than the gain score of control class. It can be caused by the level of participation or activity of students in the experimental results expressed in various forms of representation is quite high. It also can not be separated from the philosophy of multi representation stating that the learning model multi representation is also learning model that emphasizes the student's activity to the fullest to find and express its findings with diverse representation, which means that this model also puts the student as a subject of study. This means that there is a positive influence learning model multi representation against generic science skills class XI student of SMAN 4 Purworejo. In general the results of the calculation of the gain scores with the application of multi-representation compared with a gain score of the application of conventional models, as presented in Table 3 shows the average value of gain score better on inquiry learning model by 0.73 and included a high category while for the conventional model simply by 0.33 and medium category.

Table 3: Results of N-Gain on Multirepresentasi Learning in SMAN 4 Purworejo

\begin{tabular}{lll}
\hline Class & N-gain & Information \\
\hline Experiment & 0,73 & High \\
\hline Control & 0,30 & Medium \\
\hline
\end{tabular}

Both of these results are supported by previous studies conducted by Abdurrahman, et al (2011) regarding the application of learning models of multi representation on the matter of 
quantum physics. Based on his research generic science skills and critical thinking skills of students increased. Emi \& Fatmaryanti (2016) has stated that there are significant application of learning models of multi representation of the generic science skills of students. Similarly, research conducted by Samadin (2012) applying inquiry model, the research results concluded that generic science skills of students increased in general with the highest scores on indicators of generic science skills symbolic language. Munawaroh \& Fatmaryanti (2016) has stated that there are effects of the application of guided inquiry learning model to the generic science skills of students.

Based on these results it can be concluded that students' generic science skills can be improved through the application of SCL approach to learning. From the findings of the weaknesses of the two models at the time of the application in the classroom it is very possible collaboration between the two models is to further streamline the learning improvement of generic science skills. 


\section{REFERENCES}

Abdurrahman, Liliasari, Rusli A., \& Waldrip B. (2011). Implementasi pembelajaran berbasis multi representasi untuk meningkatkan penguasaan konsep kuantum. Cakrawala Pendidikan. Tahun XXX. No 1.

Arends, R. I. (2013). Learning to teach. Salemba Humanika: Jakarta.

Brotosiswoyo, B.S. (2001). Hakikat pembelajaran MIPA dan kiat pembelajaran fisika di perguruan tinggi. Proyek Pengembangan Universitas Terbuka. Direktorat Jendral Pendidikan Tinggi. Depdiknas. Jakarta.

Carolan,J., Prain, V., \& Waldrip, B. (2008). Using representations for teaching and learning in science, 54(1), 18-23.

Emi \& Fatmaryanti. (2016). Pengaruh model pembelajaran multi representasi terhadap keterampilan generik sains siswa SMA. Skripsi. UM Purworejo

Fatmaryanti,S.D \& Sarwanto. (2014). Profil kemampuan representasi pada mahasiswa prodi pendidikan Fisika UM Purworejo. Jurnal Pendidikan Fisika dan Keilmuan_

Izhak \& Sherin, M.G. (2003). Exploring the use of new representation as a resource for teaching learning. The University of Georgia and North Western University, Journal School Science and Mathematics,103(1)

Kohl P. B.,1 Rosengrant D. \& Finkelstein N.D. (2007). Strongly and weakly directed approaches to teaching multiple representation use in physics. Physics Education Research

Kuhlthau. C.C., Maniotes, L.K. \& Caspari, A.K.. (2007). Guided Inquiry: Learning in the $21^{\text {st }}$ Century. USA

Liliasari. 2007. Scientific concept and generic science skill relationship in the $21^{\text {st }}$ Century Science Education. Bandung: SPS UPI

Loi, Ngazizah,N \& Sriyono. (2016). Analisis keterampilan generik sains pada siswa kelas X se-Kabupaten Purworejo. Jurnal Radiasi. Universitas Muhammadiyah Purworejo

Munawaroh \& Fatmaryanti, S.D. (2016). Pengaruh model pembelajaran inkuiri terbimbing terhadap keterampilan generik sains siswa SMA. Skripsi. UM Purworejo

Samadin. (2012). Penerapan pembelajaran inkuiri model silver untuk mengembangkan keterampilan generik sains siswa pada konsep sifat koligatif larutan. Bandung: UIN Sunan Gunung Jati.

Sanjaya, W. (2014). Strategi pembelajaran. Jakarta: Kencana Prenadamedia Group.

Slavin, R. (2009). Psikologi pendidikan: Teori dan praktik. Terj. Samosir, M. Jakarta: Indeks 


\section{SCIENCE GENERIC SKILLS IMPROVEMENT THROUGH}

Sugiyono. (2009). Metode penelitian pendidikan: Pendekatan kuantitatif, kualitatif dan R\&D. Bandung: Alfabeta

Tawil, M., \& Liliasari. (2014). Keterampilan-keterampilan sains dan implementasinya dalam pembelajaran IPA. Makasar: Badan Penerbit UNM

Tytler,R., Prain,V., Hubber.P., \& Waldrip.B. (2013). Constructing epresentations to learn in science, 1-14. Sense Publishers.

Wright, B.G. 2011. Student centerd learning in higer education. International Journal of Teaching and Learning in Higher Education 2011, Volume 23, Number 3, 92-97.

Yeung, A.S., Chistina \& Liu, W.P. (2007). Generic capabilities for lifelong education: Conceptualization and construct validity. Australian Association for Research in Education, Frementle. 